\title{
The Pathological Significance and Prognostic Roles of Thrombospondin-1, and -2, and 4N1K-peptide in Bladder Cancer
}

\author{
YUICHIRO NAKAMURA, YASUYOSHI MIYATA, KOSUKE TAKEHARA, AKIHIRO ASAI, \\ KENSUKE MITSUNARI, KYOHEI ARAKI, TOMOHIRO MATSUO, KOJIRO OHBA and HIDEKI SAKAI \\ Department of Urology, Nagasaki University Graduate School of Biomedical Sciences, Nagasaki, Japan
}

\begin{abstract}
Background/Aim: Thrombospondins (TSPs) play a role as inhibitors of angiogenesis under various pathological conditions. The aim of the study was to evaluate the pathological significance and prognostic role of the $4 N 1 K$-peptide (KRFYVVMWKK), which is derived from TSP-1 and -2, in bladder cancer. Materials and Methods: Two-hundred and six bladder cancer tissues were examined for expression of TSP-1, TSP-2, and 4N1Kpeptide by immunohistochemistry. Cancer cell proliferation, apoptosis, angiogenesis and matrix metalloproteinase (MMP)-9 immunoreactivity were also examined. Results: Expression of TSP-2 and 4N1K-peptide was negatively associated with $T$ stage, metastasis, and grade. TSP-2 expression was negatively associated with cancer cell proliferation and MMP-9 expression, whereas $4 N 1 \mathrm{~K}$ peptide was significantly associated with apoptosis, angiogenesis, and MMP-9 expression. Multivariate analysis showed that 4N1K-peptide expression was a significant predictor of metastasis (hazard ratio $=3.90, p=0.002$ ). Conclusion: TSP-2 and $4 N 1 \mathrm{~K}$ peptide played important roles in malignant aggressiveness and progression of bladder cancer via complex mechanisms involving cell proliferation, apoptosis, angiogenesis, and MMP-9.
\end{abstract}

Thrombospondin (TSP) is a family of glycoproteins composed of 5 subtypes encoded by specific genes (TSP-1 to -5$)$. Many studies have verified that TSP-1 has antiangiogenic activities under various pathological conditions,

Correspondence to: Yasuyoshi Miyata, MD, Ph.D., Department of Nephro-Urology, Nagasaki University Graduate School of Biomedical Sciences, 1-7-1 Sakamoto, Nagasaki 852-8501, Japan. Tel: +81 958497340, Fax: +81 958497343, e-mail: yasumyt@nagasaki-u.ac.jp

Key Words: Thrombospondins, 4N1K-peptide, bladder cancer, pathological features, prognosis. including cancers (1-7). However, TSP-1 has also been shown to stimulate malignant aggressiveness of several cancers (8-11). As such, it is still uncertain whether TSP-1 has pro- or anti-cancer effects. TSP-1 and TSP-2 genes show a high degree of sequence homology (12). Interestingly, TSP-2 has stronger inhibitory effects on tumor growth and angiogenesis compared to TSP-1 $(13,14)$. Actually, several investigators have reported that TSP-2 is a negative regulator of cancer-related angiogenesis and tumour aggressiveness in a variety of cancers $(4,15-18)$. However, other investigators have suggested that TSP-2 is not involved in tumor growth and cancer cell invasion $(19,20)$. In urothelial cancer, TSP-2 has been reported to be positively associated with pathological features and vascular invasion, and was identified as predictor of worse prognosis for metastasis-free and disease specific survival (21). However, unfortunately, there is no additional study regarding the pathological significance of TSP-2 in bladder cancer (BC), and the detailed molecular mechanisms of such TSP-2-mediated activities in BC tissues are not fully understood.

The biological activities of TSPs are closely related to their derived fragments and proteins (22-24). For example, the collagen I overlap (NGVQYRN) derived from the procollagen homology domain is associated with angiogenesis in vivo (22). Therefore, in the present study, we focused on the pathological significance and prognostic roles of TSP-1, -2, and the 4N1K peptide (KRFYVVMWKK), which is derived from the C-terminal cell-binding domain of TSP-1 and TSP-2, for the following reasons: 1) there is no information on the pathological significance and prognostic role of $4 \mathrm{~N} 1 \mathrm{~K}$-peptide in $\mathrm{BC}$ patients despite the fact that it has been suggested as a potential therapeutic target and a useful predictive factor in other cancers $(25-27), 2)$ the pathological molecular mechanisms involved with the TSPs and the $4 \mathrm{~N} 1 \mathrm{~K}$-peptide are not clear, and 3) comprehensive understanding of the functions/effects of TSPs and their derived peptide is important regarding the treatment and observation strategies in patients with $\mathrm{BC}$. 


\section{Materials and Methods}

Patients. Two-hundred and six consecutive patients who were diagnosed with urothelial cancer of the urinary bladder were reviewed retrospectively. This study included 162 men and 44 women, ranging in age from 39 to 93 years (median age: 71 years). $\mathrm{T}$ stage was divided into the following groups: low- $(\mathrm{pTa}+1)$ and high-stage $(\geq \mathrm{T} 2)$. In addition, lymph node metastasis and distant metastasis coalesced into the term metastasis, for statistical analysis. We also examined 20 tissue samples of normal urinary bladders obtained from apparently normal areas of the bladder of patients with transitional cell carcinoma of the upper urinary tract. Survival analyses were performed in patients who had undergone potential curative transurethral resection $(\mathrm{n}=185)$. In short, patients with nonmetastatic tumor with $\mathrm{Ta}-1$ and pT2 were enrolled. Among these patients, intravesical therapy was performed for 162 patients $(87.6 \%)$ as adjuvant therapy. The median duration of follow-up was 57 months (interquartile range $=24-95$ months).

Immunohistochemistry. Five-micrometer-thick sections were deparaffinized in xylene and rehydrated in ethanol. All sections were subjected to antigen retrieval and then immersed in hydrogen peroxide to block endogenous peroxidase activity. The specificity of the anti-4N1K-peptide has been confirmed in several other reports $(25,26)$. The other antibodies were obtained as follows: anti-TSP-1 and -TSP-2 from Santa Cruz Biotechnology Inc. (Dallas, TX, USA), anti-Ki-67 and anti-CD34 from Dako Corp. (Grostrup, Denmark), anti-matrix metalloproteinase-9 (MMP-9) from Daiichi Fine Chemical (Toyama, Japan), and anti-cleaved caspase-3 antibody from R \& D Systems, Inc. (Abingdon, UK). Sections were incubated with the primary antibody at $4^{\circ} \mathrm{C}$ overnight. Then, the sections were washed extensively and treated with peroxidase using the labeled polymer method with DAKO EnVision+TM Peroxidase (Dako Corp., Carpinteria, CA, USA). The peroxidase reaction was visualized with the liquid DAB substrate kit (Zymed Laboratories Inc., San Francisco, CA, USA). Sections were counterstained with hematoxylin. Immunohistochemical staining of a positive control was performed as has been described previously for all antibodies except TSP-2 (2830). For TSP-2, the spleen was used as a positive control according to the manufacturer's data sheet. For evaluation of immunohistochemical staining for TSP-1, TSP-2, and 4N1K-peptide, the intensity was graded as none, weak, moderate, or strong, and then specimens with moderate or intense staining in $>10 \%$ of cells were judged as positive. The evaluation of immunohistochemical staining for Ki-67, CD34, and MMP-9 and apoptotic cells were performed as has been previously described (28-30). For all variables, values above the median were considered as the high expression group, and those with staining equal to or less than the median value were considered as the low expression group, for statistical analyses. Slides were examined using an E-400 microscope (Nikon, Tokyo, Japan) producing digital images, which were examined using a computeraided image analysis system (Win ROOF version 5.0; MITANI, Fukui, Japan). Slides were evaluated twice at different times by three investigators (Y.M., T.M., and A.A.), who were blinded to the clinicopathological features and survival data.

Ethics and statistical analyses. The study was conducted according to the Helsinki II Declaration and it was approved by the Ethics Review Committee of the Nagasaki University Hospital (No. 12052899). Written informed consent was obtained from all the patients involved in our study before their enrollment. Data are expressed as medians (interquartile range), unless otherwise stated. The Mann-Whitney $U$-test was performed for continuous variables, and the chi-square test was used for categorical comparison of the data. The raw and adjusted effects on stage and grade, as well as other pathological factors, were estimated by logistic regression analysis, and are described as odds ratios (OR) with $95 \%$ confidence intervals $(95 \% \mathrm{CI})$, together with the associated $p$-values. The metastasis-free survival rates were compared with Kaplan-Meier analysis and a log-rank test. All statistical analyses were performed using the statistical package StatView for Windows (Version 5.0).

\section{Results}

TSP-1, TSP-2, and 4N1K-peptide expression and clinicopathological features. In normal urothelial cells, all specimens were judged as positive for TSP-1, -2, and 4N1Kpeptide, because almost all cells showed moderate or strong staining (Figure 1A-C). In cancer tissues, all immunostainings were detected in both the cancer cell cytoplasm and stromal cells (Figure 1D-F). Finally, positively stained ratio of TSP-1, TSP-2, and 4N1K-peptide was $41.7 \%, 42.7 \%$, and $60.7 \%$, respectively. Chi-square test showed that TSP-1 expression was not significantly associated with TSP-2 $(p=0.176)$ or $4 \mathrm{~N} 1 \mathrm{~K}$-peptide expression $(p=0.093)$. However, TSP-2 expression was positively associated with 4N1K-peptide expression $(p<0.001)$. As shown in Table I, TSP-1 expression was not significantly related to any pathological feature. However, TSP-2 staining was significantly lower in specimens from patients diagnosed at high $\mathrm{T}$ stage, with presence of metastasis, and a high grade than in those from patients diagnosed at low $\mathrm{T}$ stage, with absence of metastasis, and a low grade $(p<0.001,0.021$, and 0.018 , respectively). Similarly, negative relationships were found between $4 \mathrm{~N} 1 \mathrm{~K}-$ peptide expression and $\mathrm{T}$ stage, metastasis, and grade $(p<0.0 .01,0.025,0.002$, respectively). On the other hand, a multivariate analysis model including all pathological features and expression of TSP- 1 and -2 demonstrated that $4 \mathrm{~N} 1 \mathrm{~K}$-peptide expression was independently associated with TSP-2 expression $(\mathrm{OR}=3.00,95 \% \mathrm{CI}=1.58-5.72, p<0.001)$, but not with TSP-1 expression (Table II).

Correlations with cancer-related factors. Relationships between the expression of TSP-1, TSP-2, and 4N1K-peptide and proliferation index (PI), apoptotic index (AI), microvessel density (MVD), and MMP-9 expression are shown in Table III. With regard to cancer cell proliferation, a negative correlation was detected with TSP-2 expression $(p=0.005)$, but not with TSP-1 and 4N1K-peptide expression. By contrast, AI and MVD were significantly associated with $4 \mathrm{~N} 1 \mathrm{~K}$-peptide expression ( $p<0.001$ and 0.024 , respectively), but not with the expression of TSP-1 or TSP-2. The AI in the TSP-2-positive tissues tended to be higher than that in TSP- 

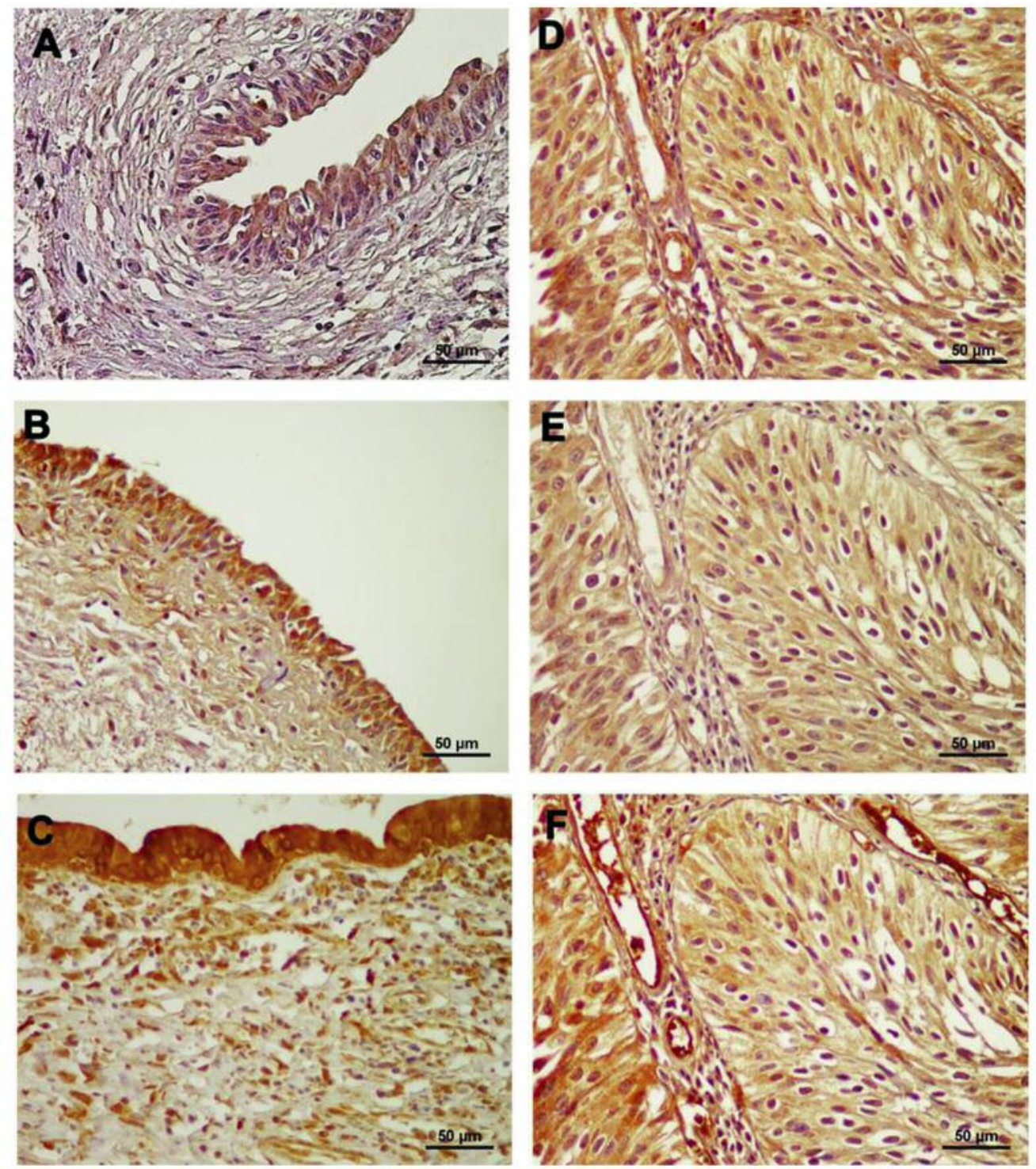

Figure 1. Representative examples of TSP-1, TSP-2, and 4N1K-peptide expression. Immunohistochemistry for TSP-1, TSP-2, and 4N1K-peptide detected in normal urothelial cells $(A-C)$ and cancer cells $(D-F)$. In normal urothelium, moderate or strong staining was detected in almost all cells. There was no remarkable difference in staining patterns of the cells in cancer tissues. Although vascular endothelial cells (arrows) were mainly stained for $4 N 1 K$-peptide $(F)$, such staining was not found for TSP-2 (E).

2-negative tissues; however, the difference did not reach a statistical significance $(p=0.071)$. MMP-9 expression was negatively associated with the expression of TSP-2 $(p<0.001)$ and $4 \mathrm{~N} 1 \mathrm{~K}$-peptide $(p=0.005)$. Furthermore, multivariate analysis model including all pathological features showed that TSP-2 expression was significantly associated with MMP-9 expression $(\mathrm{OR}=0.33,95 \% \mathrm{CI}=0.17-0.64, p=0.001)$, and a similar independent correlation was detected between $4 \mathrm{~N} 1 \mathrm{~K}$ peptide expression and MVD $(\mathrm{OR}=0.52,95 \% \mathrm{CI}=0.29-0.95$, $p=0.033$; Table IV).
Survival analyses. As shown in Figure 2A, there was no significant difference in the occurrence of subsequent metastasis according to TSP-1 expression. However, the metastasis-free survival periods in patients with TSP-2positive tissues were significantly longer than those with negative TSP-2 expression ( $p<0.001$, Figure $2 \mathrm{~B})$. A similar finding was obtained with respect to $4 \mathrm{~N} 1 \mathrm{~K}$-peptide expression $(p<0.001$, Figure 2C). In this study population, the subsequent metastasis-free survival period was significantly associated with a high $\mathrm{T}$ stage $(\mathrm{HR}=7.48,95 \% \mathrm{CI}=3.76-14.90, p<0.001)$ 
Table I. Correlation with clinicopathological features.

\begin{tabular}{|c|c|c|c|c|c|c|}
\hline & \multicolumn{2}{|c|}{ Thrombosponin-1 } & \multicolumn{2}{|c|}{ Thrombospondin-2 } & \multicolumn{2}{|c|}{ 4N1K-peptide } \\
\hline & $\begin{array}{l}\text { Negative } \\
(\mathrm{n}=120)\end{array}$ & $\begin{array}{c}\text { Positive } \\
(\mathrm{n}=86)\end{array}$ & $\begin{array}{c}\text { Negative } \\
(\mathrm{n}=118)\end{array}$ & $\begin{array}{l}\text { Positive } \\
(\mathrm{n}=88)\end{array}$ & $\begin{array}{l}\text { Negative } \\
(\mathrm{n}=81)\end{array}$ & $\begin{array}{l}\text { Positive } \\
(\mathrm{n}=125)\end{array}$ \\
\hline \multicolumn{7}{|l|}{ Age (years) } \\
\hline$\leq 71$ & $61(50.8)$ & $43(50.0)$ & $55(46.7)$ & $49(55.7)$ & $40(49.4)$ & $64(51.2)$ \\
\hline$>71$ & $59(49.2)$ & $43(50.0)$ & $63(53.3)$ & $39(44.3)$ & $41(50.6)$ & $61(48.8)$ \\
\hline$p$-Value & 0.906 & & 0.198 & & 0.799 & \\
\hline \multicolumn{7}{|l|}{ Gender } \\
\hline Male & $94(78.3)$ & $68(791)$. & $91(77.1)$ & $71(80.7)$ & $62(76.5)$ & $100(80.0)$ \\
\hline Female & $26(21.7)$ & $18(20.9)$ & $27(22.9)$ & $17(19.3)$ & $19(23.5)$ & $25(20.0)$ \\
\hline$p$-Value & \multicolumn{2}{|c|}{0.899} & \multicolumn{2}{|c|}{0.537} & \multicolumn{2}{|c|}{0.554} \\
\hline \multicolumn{7}{|l|}{ T stage } \\
\hline $\mathrm{Ta}$ & $37(30.8)$ & $23(26.7)$ & $26(22.0)$ & $34(38.6)$ & $13(16.0)$ & $47(37.6)$ \\
\hline $\mathrm{T} 1$ & $50(41.7)$ & $40(46.5)$ & $49(41.5)$ & $41(46.6)$ & $35(43.2)$ & $55(44.0)$ \\
\hline $\mathrm{T} 2$ & $18(15.0)$ & $10(11.6)$ & $21(17.8)$ & $7(8.0)$ & $12(14.8)$ & $16(12.8)$ \\
\hline $\mathrm{T} 3$ & $8(6.7)$ & $10(11.6)$ & $12(10.2)$ & $6(6.8)$ & $12(14.8)$ & $6(4.8)$ \\
\hline $\mathrm{T} 4$ & $7(5.8)$ & $3(3.5)$ & $10(8.5)$ & $0(0.0)$ & $9(11.1)$ & $1(0.8)$ \\
\hline$p$-Value & \multicolumn{2}{|c|}{0.566} & \multicolumn{2}{|c|}{0.002} & \multicolumn{2}{|c|}{$<0.001$} \\
\hline Low $(\mathrm{Ta}+1)$ & $87(72.5)$ & $63(73.3)$ & $75(63.6)$ & $75(85.2)$ & $48(59.3)$ & $102(81.6)$ \\
\hline $\operatorname{High}(\mathrm{T} 2-4)$ & $33(27.5)$ & $23(26.7)$ & $43(36.4)$ & $13(14.8)$ & 33 (40.7) & $23(18.4)$ \\
\hline$p$-Value & & & & & & \\
\hline \multicolumn{7}{|l|}{ Metastasis } \\
\hline Absence & $108(90.0)$ & $77(89.5)$ & $101(85.6)$ & $84(95.5)$ & $68(84.0)$ & 117 (93.6) \\
\hline Presence & $12(20.0)$ & $9(10.5)$ & $17(14.4)$ & $4(4.5)$ & $13(16.0)$ & $8(6.4)$ \\
\hline$p$-Value & \multicolumn{2}{|c|}{0.913} & \multicolumn{2}{|c|}{0.021} & \multicolumn{2}{|c|}{0.025} \\
\hline \multicolumn{7}{|l|}{ Grade } \\
\hline Low & $44(36.7)$ & $42(48.8)$ & $41(34.7)$ & $45(51.1)$ & $23(28.4)$ & $63(50.4)$ \\
\hline High & $76(63.3)$ & $44(51.2)$ & $77(65.3)$ & $43(48.9)$ & $58(71.6)$ & $62(49.6)$ \\
\hline$p$-Value & \multicolumn{2}{|c|}{0.081} & \multicolumn{2}{|c|}{0.018} & \multicolumn{2}{|c|}{0.002} \\
\hline \multicolumn{7}{|l|}{ Adjuvant Tx } \\
\hline Nothing & $25(20.8)$ & $19(22.1)$ & 27 (22.9) & $17(19.3)$ & $16(19.8)$ & $28(22.4)$ \\
\hline Performed & $95(79.2)$ & $67(77.9)$ & $91(77.1)$ & $71(80.7)$ & $65(80.2)$ & 97 (77.6) \\
\hline$p$-Value & \multicolumn{2}{|c|}{0.828} & \multicolumn{2}{|c|}{0.537} & \multicolumn{2}{|c|}{0.651} \\
\hline
\end{tabular}

Data are shown as number (\%) of patients. Tx: Therapy.

and high grade $(\mathrm{HR}=7.47,95 \% \mathrm{CI}=2.90-19.25, p<0.001)$ according to the univariate analyses. Therefore, the independent roles of the expression of TSP-2 or 4N1K-peptide were analyzed using multivariate analysis models including pathological features (Table V). In Model A, including T stage, grade, and TSP-2 or 4N1K-peptide expression, TSP-2 and $4 \mathrm{~N} 1 \mathrm{~K}$-peptide expression were identified as independent factors to predict the occurrence of subsequent metastasis (Table V). However, in model B, which included all risk factors, 4N1K-peptide expression was also identified as a significant predictor $(\mathrm{HR}=3.90,95 \% \mathrm{CI}=1.68-9.07, p=0.002)$, whereas TSP-2 expression was not (Table V).

\section{Discussion}

Our results demonstrated that the expression of TSP-2 and $4 \mathrm{~N} 1 \mathrm{~K}$-peptide are negatively related with the malignant potential, tumor progression, and prognosis of patients with
Table II. Multivariate analysis of the correlation between 4 NIK-peptide expression and clinicopathological features and expression of TSP-1 and -2 .

\begin{tabular}{|c|c|c|c|}
\hline & \multicolumn{2}{|c|}{ For $4 \mathrm{~N} 1 \mathrm{~K}$-peptide expression } & \multirow[b]{2}{*}{$p$-Value } \\
\hline & Odds ratio & $95 \% \mathrm{CI}$ & \\
\hline T stage: low & 1.90 & $0.90-4.04$ & 0.095 \\
\hline Metastasis: absent & 1.36 & $0.44-4.16$ & 0.596 \\
\hline Grade: low & 1.58 & $0.82-3.02$ & 0.172 \\
\hline TSP-1: positive & 1.83 & $0.98-3.44$ & 0.059 \\
\hline TSP-2: positive & 3.00 & $1.58-5.72$ & $<0.001$ \\
\hline
\end{tabular}

TSP: Thrombospondin; CI: confidence interval.

BC. However, TSP-1 does not appear to play a role or has only a minimal or indirect role in these cancer-related parameters. This finding is in stark contrast to several 
Table III. Correlation between malignant aggressiveness and TSP-1, -2, or 4N1K-peptide

\begin{tabular}{|c|c|c|c|c|c|c|}
\hline & \multicolumn{2}{|c|}{ Thrombospindin-1 } & \multicolumn{2}{|c|}{ Thrombospndin-2 } & \multicolumn{2}{|c|}{ 4N1K-peptide } \\
\hline & Negative & Positive & Negative & Positive & Negative & Positive \\
\hline PI, \% & $23.9 / 8.6$ & $24.1 / 8.5$ & $24.5 / 8.3$ & $22.1 / 8.5$ & $24.9 / 8.2$ & $23.4 / 8.7$ \\
\hline$p$-Value & \multicolumn{2}{|c|}{0.878} & \multicolumn{2}{|c|}{0.005} & \multicolumn{2}{|c|}{0.203} \\
\hline AI, $\%$ & $4.35 / 1.86$ & $4.26 / 1.89$ & $4.11 / 1.89$ & $4.58 / 1.82$ & $3.75 / 1.83$ & $4.67 / 1.81$ \\
\hline p-Value & \multicolumn{2}{|c|}{0.729} & \multicolumn{2}{|c|}{0.071} & \multicolumn{2}{|c|}{$<0.001$} \\
\hline $\begin{array}{c}\mathrm{MVD}, / \mathrm{mm}^{2} \\
p \text {-Value }\end{array}$ & $62.4 / 20.5$ & $61.8 / 18.1$ & $63.0 / 19.8$ & $61.3 / 19.9$ & $66.1 / 21.2$ & $59.8 / 18.5$ \\
\hline MMP-9 & $55(45.8)$ & $37(43.0)$ & $69(58.5)$ & $23(26.1)$ & $46(56.8)$ & $46(36.8)$ \\
\hline$p$-Value & \multicolumn{2}{|c|}{0.689} & \multicolumn{2}{|c|}{$<0.001$} & \multicolumn{2}{|c|}{0.005} \\
\hline
\end{tabular}

Data are shown as mean/SD or number (\%) of positively stained specimens. PI: Proliferation index; AI: apoptotic index; MVD: microvessel density; MMP: matrix metalloproteinase.

Table IV. Multi-variate analysis of correlation between cancer-related factors and TSP-2 or 4N1K peptide*.

\begin{tabular}{|c|c|c|c|c|c|c|}
\hline & \multicolumn{3}{|c|}{ Thrombospondin-2 } & \multicolumn{3}{|c|}{ 4N1K-peptide } \\
\hline & OR & $95 \% \mathrm{CI}$ & $p$-Value & OR & $95 \% \mathrm{CI}$ & $p$-Value \\
\hline \multicolumn{7}{|l|}{ Proliferation index } \\
\hline Over median & 0.95 & $0.52-1.74$ & 0.857 & - & - & - \\
\hline \multicolumn{7}{|l|}{ Apoptotic index } \\
\hline Median or less & - & - & - & 0.56 & $0.31-1.04$ & 0.068 \\
\hline \multicolumn{7}{|l|}{ Microvessel density } \\
\hline Over median & - & - & - & 0.52 & $0.29-0.95$ & 0.033 \\
\hline \multicolumn{7}{|l|}{ MMP-9 expression } \\
\hline Positive & 0.33 & $0.17-0.64$ & 0.001 & 0.67 & $0.36-1.29$ & 0.234 \\
\hline
\end{tabular}

OR: Odds ratio; CI: confidence interval; MMP: matrix metalloproteinase. *Adjusted by T stage, metastasis, and grade.

previous studies showing that decreased expression of TSP-1 was related to high malignant potential and poor survival in BC patients $(2,3,5,7)$. In addition, regarding TSP-2, a previous report has shown that its expression was positively associated with malignant aggressiveness and a worse prognosis in BC patients (21). Although we cannot explain the reason for this apparent discrepancy in the pathological roles of TSP-1 and -2, we hypothesize that the differences among studies, including patients' backgrounds, antibodies used, or evaluation methods, might have contributed to these conflicting results. However, TSP-2 has been reported to act as an inhibitor of tumor invasion and metastasis both in vivo and in vitro in various types of cancers $(15,16,18)$. In addition, a recent study has demonstrated that TSP-2 inhibited vascular endothelial growth factor-induced cell proliferation and migration of tumor-associated blood vascular endothelial cells isolated from human bladder cancer (31). These results support our results that TSP-2 expression may play a role as tumor-suppressor and better predictor for prognosis in patients with BC.
In the present study, we demonstrated, for the first time, the pathological significance and roles of $4 \mathrm{~N} 1 \mathrm{~K}$-peptide in $\mathrm{BC}$. However, similar findings have been reported in other cancers $(26,27)$, thus, our results add to the growing body of evidence that $4 \mathrm{~N} 1 \mathrm{~K}$-peptide has anti-cancer effects. According to the results of our multivariate analysis models, we hypothesized that $4 \mathrm{~N} 1 \mathrm{~K}$-peptide was mainly derived from TSP-2, and not from TSP-1, in BC tissues. Although the mechanism contributing to this difference was not determined, it is possible that TSP-2 predominates and plays important roles in the malignant aggressiveness of $\mathrm{BC}$ cells, and consequently, its derived peptide $4 \mathrm{~N} 1 \mathrm{~K}$ also exhibits pathological activities. Our conclusion is based on two key findings: 1) 4N1K-peptide is derived from the C-terminal cell-binding domain, which exists in TSP-2, and 2) TSP-2 and $4 \mathrm{~N} 1 \mathrm{~K}$-peptide showed similar associations with cancer cell invasion, metastasis, grade, and prognosis, indicating similar pathological roles.

We also observed differences in the pathological roles between TSP-2 and 4N1K-peptide at the molecular level. In 

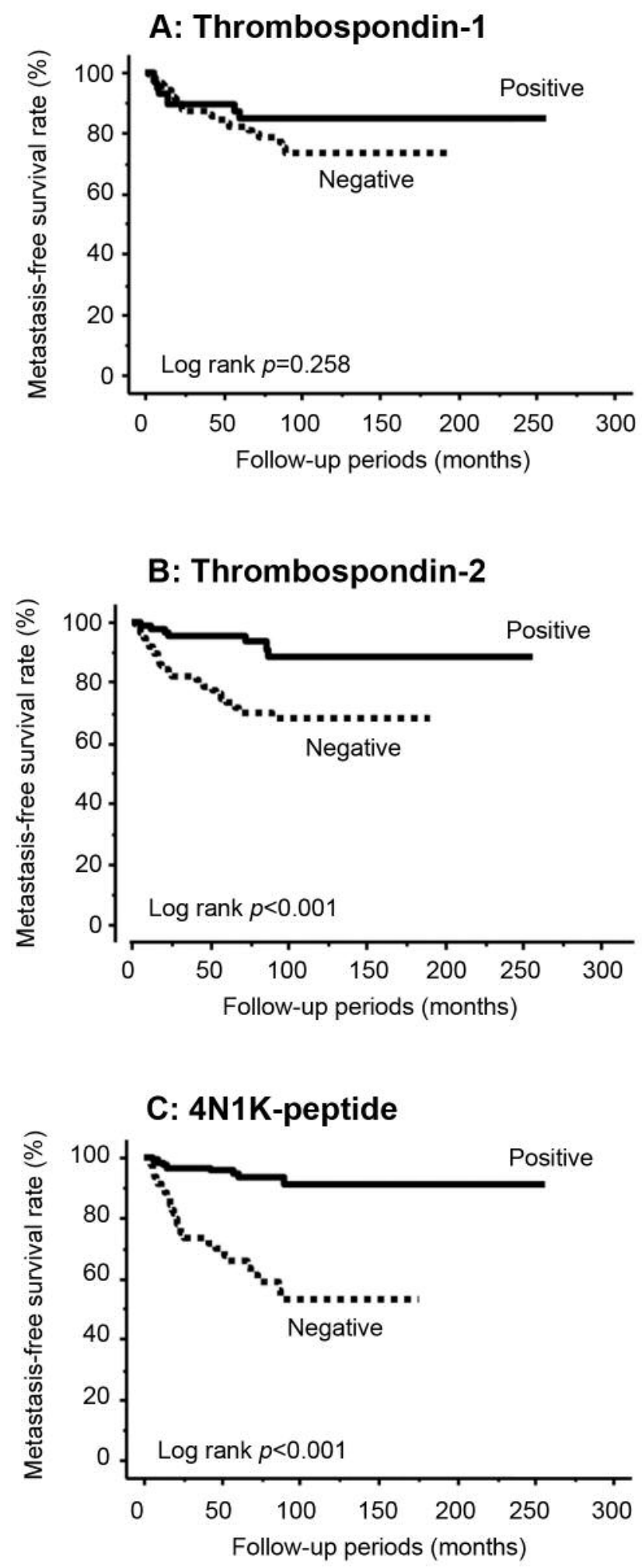

Figure 2. Kaplan-Meier survival curves for metastasis-free survival. Survival analyses for metastasis-free survival of TSP-1 (A), TSP-2 (B), and $4 N 1 K$-peptide expression $(C)$ in bladder cancer patients. Expression of TSP-2 and 4N1K-peptide were significant predictors for metastasisfree survival $(p<0.001 ; B$ and $C)$ whereas TSP-1 expression was not $(A)$.
Table V. Multivariate analyses of the correlation of TSP-1, -2, and $4 N 1 K$-peptide and subsequent metastasis.

\begin{tabular}{lllr}
\hline & \multicolumn{3}{c}{ For subsequent metastasis } \\
\cline { 2 - 4 } & HR & $95 \%$ CI & $p$-Value \\
\hline Model A & & & \\
T stage: High & 4.27 & $2.10-8.67$ & $<0.001$ \\
Grade: High & 5.46 & $2.06-14.46$ & $<0.001$ \\
TSP-2: Negative & 3.44 & $1.49-7.96$ & 0.004 \\
T stage: High & 4.00 & $1.94-8.24$ & $<0.001$ \\
Grade: High & 3.93 & $1.47-10.54$ & 0.007 \\
4N1K-peptide: Negative & 4.92 & $2.21-10.95$ & $<0.001$ \\
Model B & & & \\
T stage: High & 3.34 & $1.59-7.01$ & 0.001 \\
Grade: High & 4.26 & $1.59-11.44$ & 0.004 \\
TSP-1: Negative & 1.11 & $0.56-2.19$ & 0.774 \\
TSP-2: Negative & 2.26 & $0.93-5.52$ & 0.073 \\
4N1K-peptide: Negative & 3.90 & $1.68-9.07$ & 0.002 \\
\hline
\end{tabular}

HR: Hazard ratio; CI: confidence interval; TSP: thrombospondin.

short, our multivariate analyses showed that TSP-2 expression was negatively associated with MMP-9 expression, whereas 4N1K-peptide expression was more strongly correlated with angiogenesis in patients with $\mathrm{BC}$. With respect to the relationship between TSP-2 and MMP-9, a similar result has been previously reported in pancreatic cancer cells and in colon cancer $(15,32)$. Thus, our results extend this relationship to explaining the pathology of $\mathrm{BC}$ as well. By contrast, 4N1K-peptide expression was negatively associated with angiogenesis in $\mathrm{BC}$ tissues. 4N1K-peptide has been reported to have an anti-angiogenic function in vivo (25). In addition, its expression has been shown to be negatively associated with MVD in several cancer tissues $(26,27)$. These results, suggest that 4N1K-peptide likely plays an antiangiogenic role in patients with bladder cancer. In fact, our pathological finding showed that strong expression of $4 \mathrm{~N} 1 \mathrm{~K}-$ peptide was detected in microvessels within the tumor area.

In the survival analyses, TSP-2 and 4N1K-peptide were identified as major predictors of subsequent metastasis after operation in patients with BC. As mentioned above, TSP-2 and 4N1K-peptide expression were negatively associated with MMP-9 expression and MVD, respectively. Thus, the prognostic values of TSP-2 and 4N1K-peptide can be adequately explained by these relationships. The multivariate analysis model that included all of the pathological parameters along with TSP-1, TSP-2, and 4N1K-peptide expression showed that only $4 \mathrm{~N} 1 \mathrm{~K}$-peptide was an independent and significant predictive factor for prognosis. One potential reason for this result might be the dual biological function of TSP2 , with both pro- and anti-cancer effects. This is possible 
since TSP-2 is a large multi-domain protein and its pathological activities are regulated by various types of proteins and many molecular pathways that also depend on the tumour microenvironment (33). In short, some domains and derived peptides from TSP-2 may have a pro-angiogenic effect in BC tissues, whereas others might have anti-cancer effects.

One of the limitations of this study was that the results were not confirmed in an in vitro experiment. Therefore, more detailed studies are necessary to verify the hypotheses put forth herein. However, the in vivo data are important to understand the pathological significance of TSPs and 4N1Kpeptide. Furthermore, such detailed investigation has definitely merit in order to develop improved treatment strategies and markers for patients with BC.

\section{Conclusion}

TSP-2 and 4N1K-peptide expression were negatively associated with pathological features in patients with BC. Multivariate analysis further showed that $4 \mathrm{~N} 1 \mathrm{~K}$-peptide was mainly derived from TSP-2. On the other hand, although TSP-2 expression was significantly associated with MMP-9 expression, 4N1K-petide expression was associated with MVD. Multivariate analyses also showed that only $4 \mathrm{~N} 1 \mathrm{~K}-$ peptide expression emerged as a significant predictor for subsequent metastasis. Thus, the pathological roles of $4 \mathrm{~N} 1 \mathrm{~K}$ peptide are different from those of TSP-2, and 4N1K-peptide would be a more useful predictive marker and potential therapeutic target compared to TSP-1 and TSP-2 in patients with BC.

\section{Conflicts of Interest}

None of the Authors has any conflict of interest regarding this study.

\section{Funding/Support}

This study was supported in part by a Grant-in-Aid from Japan Society for the Promotion of Science to Yasuyoshi Miyata (25462487) and to Kosuke Takehara (15K10594).

\section{Authors' Contributions}

Study concept: YM. Study deign: YM. Clinical data collection: TM, YN, and KO. Immunohistochemical analyses: YM, AA, and KM. Statistical analyses: YM and TM. Manuscript preparation: YN, YM, and KA. Manuscript editing: KT and KO. Manuscript review: HS. All Authors read and approved the final manuscript.

\section{Acknowledgements}

The Authors wish to thank Ms. Mitsuko Yoneda for the technical support.

\section{References}

1 Lawler JW, Slayter HS and Coligan JE: Isolated and characterisation of a high molecular weight glycoprotein from human blood platelet. J Biol Chem 253: 8609-8616, 1978. PMID: 101549 .

2 Grossfeld GD, Ginsberg DA, Stein JP, Bochner BH, Esrig D, Groshen S, Dunn M, Nichols PW, Taylor CR, Skinner DG and Cote RJ: Thrombospondin-1 expression in bladder cancer: association with p53 alterations, tumor angiogenesis, and tumor progression. J Natl Cancer Inst 89: 219-227, 1997. PMID: 9017002.

3 Goddard JC, Sutton CD, Jones JL, O'Byrne KJ and Kochelbergh RC: Reduced thrombospondin-1 at presentation predicts disease progression in superficial bladder cancer. Eur Urol 42: 464-468, 2002. PMID: 12429155.

4 Lawler J: The functions of thrombospondin-1 and-2: Curr Opin Cell Biol 12: 634-640, 2000. PMID: 10978901. DOI:10.1016/ S0955-0674(00)00143-5

5 Ioachim E, Michael MC, Salmas M, Damala K, Tsanou E, Michael MM, Malamou-Mitsi V and Stavropoulos NE: Thrombo-spondin1 expression in urothelial carcinoma: prognostic significance and association with p53 alterlations, tumour angiogenesis and extracellular matrix components. BMC Cancer 6: 140-147, 2006. PMID: 16732887. DOI: 10.1186/1471-2407-6-140.

6 Ren B, Yee KO, Lawler J and Khosravi-Far R: Regulation of tumor angiogenesis by thrombospondin-1. Biochim Biophys Acta 1765: 178-188, 2006. PMID: 16406676. DOI: 10.1016/ j.bbcan.2005.11.002

7 Shariat SF, Youssef RF, Gupta A, Chade DC, Karakiewicz PI, Isbarn H, Jeldres C, Sagalowsky AI, Ashfaq R and Lotan Y: Associated of angiogenesis related markers with bladder cancer outcomes and other molecular markers. J Urol 183: 1744-1750, 2010. PMID: 20299037. DOI: 10.1016/j.juro.2010.01.018

8 Fontana A, Filleur S, Guglielmi J, Fontana A, Filleur S, Guglielmi J, Frappart L, Bruno-Bossio G, Boissier S, Cabon F and Clézardin P: Human breast tumors override the antiangiogenic effect of stromal thrombospondin-1 in vivo. Int J Cancer 116: 686-691, 2005. PMID: 15838828. DOI: $10.1002 / \mathrm{ijc} .20584$

9 Firlej V, Mathieu JR, Gilbert C, Lemonnier L, Nakhlé J, GallouKabani C, Guarmit B, Morin A, Prevarskaya N, Delongchamps $\mathrm{NB}$ and Cabon F: Thrombospondin-1 triggers cell migration and development of advanced prostate tumors. Cancer Res 71: 76497658, 2011. PMID: 22037878. DOI: 10.1158/0008-5472.CAN11-0833

10 Horiguchi H, Yamagata S, Qian ZR, Kagawa S and Sakashita N: Thorombospondin-1 is highly expressed in desmoplastic components of invasive ductal carcinoma of the breast and associated with lymph node metastasis. J Med Invest 60: 91-96, 2013. PMID: 23614916. DOI: 10.2152/jmi.60.91

11 Pal SK, Nguyen CT, Morita KI, Miki Y, Kayamori K, Yamaguchi A and Sakamoto K: THBS1 is induced by TGFB1 in the cancer stroma and promotes invasion of oral squamous cell carcinoma. J Oral Pathol Med 45: 730-739, 2016. PMID: 26850833. DOI: $10.1111 /$ jop. 12430

12 Adams JC: Thronbospondins: multifuctional regulators of cell interactions. Annu Rev Cell Dev Biol 17: 25-51, 2001. PMID: 11687483. DOI: 10.1146/annurev.cellbio.17.1.25

13 Kyriakides TR, Zhu YH, Smith LT, Bain SD, Yang Z, Lin MT, Danielson KG, Iozzo RV, LaMarca M, McKinney CE, Ginns EI 
and Bornstein P: Mice that lack thrombospondin 2 display connective tissue abnormalities that are associated with disordered collagen fibrillogenesis, an increased vascular density, and a bleeding diathesis. J Cell Biol 140: 419-430, 1998. PMID: 9442117. DOI: 10.1083/jcb.140.2.419

14 Streit M, Riccardi L, Velasco P, Brown LF, Hawighorst T, Bornstein $\mathrm{P}$ and Detmar M: Thrombospondin-2: a potent endogenous inhibitor of tumor growth and angiogenesis. Proc Natl Acad Sci USA 96: 14888-14893, 1999. PMID: 10611308. DOI: $10.1073 /$ pnas.96.26.14888

15 Nakamura M, Oida Y, Abe Y, Yamazaki H, Mukai M, Matsuyama M, Chijiwa T, Matsumoto $\mathrm{H}$ and Ueyama $\mathrm{Y}$ : Thrombospondin-2 inhibits tumor cell invasion through the moduration of MMP-9 and uPA in pancreatic cancer cells. Mol Med Rep 1: 423-427, 2008. PMID: 21479427. DOI: 10.3892/ mmr.1.3.423

16 Koch M, Hussein F, Woeste A, Gründker C, Frontzek K, Emons $\mathrm{G}$ and Hawighorst T: CD36-mediated activation of endothelial cell apoptosis by an N-terminal recombinant fragment of thrombospondin-2 inhibits breast cancer cell growth and metastasis in vivo. Breast Cancer Res Treat 128: 337-346, 2011. PMID: 20714802. DOI: 10.1007/s10549-010-1085-7

17 Sun R, Wu J, Chen Y, Lu M, Zhang S, Lu D and Li Y: Down regulation of thrombospondin2 predicts poor prognosis in patients with gastric cancer. Mol Cancer 13: 225, 2014. PMID: 25262009. DOI: 10.1186/1476-4598-13-225

18 Lin CY, Lin CY, Chang IW, Sheu MJ, Li CF, Lee SW, Lin LC, Lee YE and He HL: Low thrombospondin 2 expression is predictive of low tumor regression after neoadjuvant chemoradiotherapy in rectal cancer. Am J Transl Res 7: 24232432, 2015. PMID: 26807188.

19 Chijiwa T, Abe Y, Inoue Y, Matsumoto H, Kawai K, Matsuyama M, Miyazaki N, Inoue H, Mukai M, Ueyama Y, and Nakamura M: Cancerous, but not stromal, thrombospondin-2 contributes prognosis in pulmonary adenocarcinoma. Oncol Rep 22: 279283, 2009. PMID: 19578767. DOI: 10.3892/or_00000435

20 Matos AR, Coutinho-Camillo CM, Thuler LC, Thuler LC, Fonseca FP, Soares FA, Silva EA and Gimba ER: Expression analysis of thrombospondin 2 in prostate cancer and benign prostatic hyperplasia. Exp Mol Pathol 94: 438-444, 2013. PMID: 23470460. DOI: 10.1016/j.yexmp.2013.02.002

21 Chang IW, Li CF, Lin VC, He HL, Liang PI, Wu WJ, Li CC and Huang CN: Prognostic impact of Thrombospodin-2 (THBS2) overexpression on patients with urothelial carcinomas of upper urinary tracts and bladders. J Cancer 7: 1541-1549, 2016. PMID: 27471570. DOI: $10.7150 /$ jca. 15696

22 Guo NH, Krutzsch HC, Inman JK and Robert DD: Thrombospondin 1 and type I repeat peptides of thrombospondin 1 specifically induced apoptosis of endothelial cells. Cancer Res 57: 1735-1742, 1997. PMID: 9135017.

23 Saumet A, Slimane BM, Lanotte M, Lawler J and Dubermrd V: Type 3 repeat/C-terminal domain of thrombospondin-1 triggers caspase-independent cell death though $\mathrm{CD} 47 / \alpha v \beta 3$ in promyelocytic leukemia NB4 cells. Blood 106: 658-667, 2005. PMID: 15784731. DOI: 10.1182/blood-2004-09-3585
24 De Fraipont F, Keramidas M, El Atifti M, Chambaz EM, Berger $\mathrm{F}$ and Feige JJ: Expression of thrombospondin 1 fragmant 167569 in C6 glioma cells stimulates tumorgenecity despite reduced neovascularization. Oncogene 23: 3642-3649, 2004. PMID: 15077189. DOI: 10.1038/sj.onc. 1207438

25 Kanda S, Shono T, Tomasini-Johansson B, Klint P and Saito Y: Role of thrombospondin-1 derived peptide, 4N1K, in FGF-2induced angiogenesis. Exp Cell Res 252: 262-272, 1999. PMID: 10527617. DOI: 10.1006/excr.1999.4622

26 Miyata Y, Koga S, Takehara K, Kanetake H and Kanda S: Expression of thrombospondin-derived $4 \mathrm{~N} 1 \mathrm{~K}$ peptide-containing proteins in renal cell carcinoma tissues is associated with a decrease in tumor growth and angiogenesis. Clin Cancer Res 9: 1734-1740, 2003. PMID: 12738728.

27 Miyata Y, Watanabe S, Kanetake $H$ and Sakai H: Thrombospondin-1-derived $4 \mathrm{~N} 1 \mathrm{~K}$ peptide expression is negatively associated with malignant aggressiveness and prognosis in urothelial carcinoma of the upper urinary tract. BMC Cancer 12: 372, 2012. PMID: 22928942. DOI: 10.1186/1471-2407-12-372

28 Maruta S, Miyata Y, Sagara Y, Kanda S, Iwata T, Watanabe SI, Sakai H, Hayashi $\mathrm{T}$ and Kanetake H: Expression of matrix metalloproteinase-10 in non-metastatic prostate cancer: Correlation with an imbalance in cell proliferation and apoptosis. Oncol Lett 1: 417-421, 2010. PMID: 22966318. DOI: 10.3892/ol_00000073

29 Miyata Y, Watanabe S, Sagara Y, Mitsunari K, Matsuo T, Ohba $\mathrm{K}$ and Sakai H: High expression of HuR in cytoplasm, but not nuclei, is associated with malignant aggressiveness and prognosis in bladder cancer. PLoS One 8: e59095, 2013. PMID: 23516604. DOI: 10.1371/journal.pone.0059095

30 Miyata Y, Kanda S, Mitsunari K, Asai A and Sakai H: Heme oxygenase-1 expression is associated with tumor aggressiveness and outcomes in patients with bladder cancer: a correlation with smoking intensity. Transl Res 164: 468-476, 2014. PMID: 25063314. DOI: $10.1016 /$ j.trs1.2014.06.010

31 Roudnicky F, Yoon SY, Poghosyan S, Schwager S, Poyet C, Vella G, Bachmann SB, Karaman S, Shin JW, Otto VI and Detmar M: Alternative transcription of a shorter, non-antiangiogenic thrombospondin-2 variant in cancer-associated blood vessels. Oncogene 37: 2573-2585, 2018. PMID: 29467494. DOI: $10.1038 / \mathrm{s} 41388-018-0129-\mathrm{z}$

32 Kamochi J, Tokunaga T, Tomii Y, Abe Y, Hatanaka H, Kijima H, Yamazaki H, Watanabe N, Matsuzaki S, Ueyama Y and Nakamura M: Overexpression of the thrombospondin 2 (TSP2) gene modulated by the matrix metalloproteinase family expression and production in human colon carcinoma cell line. Oncol Rep 10: 881-884, 2003. PMID: 12792739. DOI: $10.3892 /$ or.10.4.881

33 Lawler PR and Lawler J: Molecular basis for the regulation of angiogenesis by thrombospondin-1 and -2 . Cold Spring Harb Perspect Med 2: a006627, 2012. PMID: 22553494. DOI: $10.1101 /$ cshperspect.a006627

Received March 30, 2019 Revised April 18, 2019 Accepted April 19, 2019 